ISSN 0258-7122

Bangladesh J. Agril. Res. 34(4) : 565-576, December 2009

\title{
EFFECT OF HARVESTING STAGES ON THE SEED QUALITY OF LENTIL (Lens culinaris L.) DURING STORAGE
}

\begin{abstract}
A. KHATUN ${ }^{1}$, G. KABIR ${ }^{2}$ AND M. A. H. BHUIYAN ${ }^{3}$
Abstract

Laboratory experiments were carried out during August to September 2004 and 2005 at the Seed Technology Laboratory, Bangladesh Agricultural Research Institute, Gazipur, Bangladesh to determine the effects of harvesting stages on the seed quality of lentil. Lentil seeds of three varieties were harvested at three stages at 7-day intervals viz. i) when the pods were yellowish with a few yellow greens $\left(\mathrm{H}_{1}\right.$ stage), $\mathrm{ii}$ ) when most of the pods were light brown with a few yellow $\left(\mathrm{H}_{2}\right.$ stage), and iii) when all the pods were completely brown and dry $\left(\mathrm{H}_{3}\right.$ stage). All the seeds were stored in earthen pot until conducting the laboratory study. Non-significant variation was observed in three varieties of lentil for most of the parameters studied. The highest germination percentage, root length, shoot length, seedling length and vigour index (vigour index-I and vigour index-Il) were observed in BARI Masur-4, and the lowest in BARI Masur-2. Harvesting stage had significant effect on some parameters studied. Seeds collected at the stage when most of the pods were light brown with a few yellow $\left(\mathrm{H}_{2}\right.$ stage) recorded the highest germination percentage, dry weight, root length, shoot length, seedling length and vigour index (vigour index-I and vigour-Il) in both the years. BARI Masur-4 seeds collected at $\mathrm{H}_{2}$ stage recorded the highest dry weight and vigour index-I in both the years and vigour index-Il in 2004.
\end{abstract}

Key Words: Lentil, harvesting stage, storage, seed quality.

\section{Introduction}

Seed development is the period between fertilization and maximum fresh weight accumulation and seed maturation begins at the end of seed development and continues till harvested (Mehta et al., 1993). The seed reaches its maximum dry weight at physiological maturity. Studies on seed development and physiological maturity become important because seeds should be harvested at proper time to ensure their quality in terms of germinability and vigour. If the seeds are retained on mother plant after physiological maturity, physiological changes in seed may lead to formation of hard seeds or off colour seeds in pulse crops.

Storability of seeds is mainly a genetical character and is influenced by prestorage history of seed, seed maturation and environmental factors during preand post-harvest stages (Mahesha et al., 2001b). Early harvested seeds will be

\footnotetext{
${ }^{1}$ Senior Scientific Officer, Planning and Evaluation Division, Bangladesh Agricultural Research Institute, Joydebpur, Gazipur 1701, ${ }^{2}$ Professor, Department of Botany, University of Rajshahi, Rajshahi 6205, ${ }^{3}$ Senior Scientific Officer, Soil Science Division, Bangladesh Agricultural Research Institute, Joydebpur, Gazipur 1701, Bangladesh.
} 
immature and poorly developed and as such are poor storers compared to seed harvest at physiological maturity (Singh and Lachanna, 1995; Deshpande et al., 1991).

At physiological maturity, seed shall have maximum viability and vigour. Attainment of physiological maturity is a genotypic character which is influenced by environmental factors (Kole and Gupta, 1982; Mahesha et al., 2001a). As such harvesting of seed crop at optimum stage of seed maturation is essential to obtain better seed quality.

Harvesting time of any crop for seed quality depends on its maturity time and on physiological maturity. Harvesting of seeds at optimum stage of maturity helps to obtain better quality seed. Harvesting stage influences the quality of seed in relation to germination, vigour, viability and also storability. Seed quality in storage is also influenced by the condition, which has not yet been studied for lentil seed storage. Therefore, investigation was carried out to find out the physiological maturity of harvested seeds of lentil in their seed quality.

\section{Materials and Method}

Experiments were carried out at Seed Technology Division Laboratory in the Bangladesh Agricultural Research Institute (BARI), Joydebpur, Gazipur during the period from August to September 2004 and 2005. The experiment was conducted to determine the effects of harvesting stages on seed quality of lentil under laboratory conditions. Previously lentil seeds of three varieties viz. BARI Masur-2, BARI Masur-3 and BARI Masur-4 were collected from Pulses Research Centre experimental field in rabi seasons of 2003-04 considering three different times of harvesting at 7-day intervals, viz. i) when the pods were yellowing with a few yellow greens $\left(\mathrm{H}_{1}\right.$ stage), ii) when most of the pods were light brown with a few yellow $\left(\mathrm{H}_{2}\right.$ stage), and iii) when all the pods were completely brown and dry ( $\mathrm{H}_{3}$ stage). The collected seeds were preserved in the earthen pot. Before setting up the field experiment, laboratory experiment was carried out for recording the seed quality data. Laboratory experiments were conducted in complete randomized design with the above seeds of lentil which were collected from Pulses Research Centre, BARI, Joydebpur, Gazipur. The following quality parameters and seed vigour contributing characters were recorded:

Determination of moisture content: The moisture content of seed samples was determined according to ISTA (1976). Moisture content data were taken during August 2004 and 2005 at Seed Technology Division Laboratory of BARI. Ground (10 g) seed samples of each lentil variety were taken into moisture cup 
and put into a pre-heated oven at temperature of $103 \pm 2{ }^{\circ} \mathrm{C}$ for one hour according to Morshed et al. (2003). Three replicates were taken. After cooling, the weight of the container with its cover and contents were taken. The seed samples were cooled in desiccators and weighed to work out the percent moisture content of the grains. The seed moisture content was determined by dry weight basis and was calculated by the following formula:

$\left\{\left(\mathrm{M}_{2}-\mathrm{M}_{3}\right) /\left(\mathrm{M}_{2}-\mathrm{M}_{1}\right)\right\} \times 100$

Where, $\mathrm{M}_{1}$ is the weight in grams of the container and its cover,

$\mathrm{M}_{2}$ is the weight in grams of the container, its cover and its contents before drying

and $\mathrm{M}_{3}$ is the weight in grams of the container, its cover and contents after drying.

Determination of germination percentage: Germinations were carried out according to ISTA (1976). For each treatment, 100 seeds were put into petri dishes. Four replicates were used. The petri dishes were put up on a laboratory table at room temperature $\left(25 \pm 2^{\circ} \mathrm{C}\right)$. After eight days, normal, abnormal and diseased seeds were counted.

Measurement of root and shoot length: After eight days, ten plants were randomly selected for study, taking from each replicate of each treatment. The seedlings were cut into root and shoot parts and their lengths were measured (in $\mathrm{cm})$.

Determination of fresh and dry weight of seedling: After measuring the root and shoot length as described above, fresh weight of seedlings was recorded. Then the root and shoot were put into paper packet separately, and placed into the preheated oven $\left(70^{\circ} \mathrm{C}\right)$ for 48 hours. After cooling in desiccators, the dry weight was taken.

Determination of seed vigour: Seedling vigour was calculated based on the following formulae (Reddy and Khan, 2001):

Vigour index-I: Percent germination $\mathrm{x}$ total dry weight of seedling.

Vigour index-Il: Percent germination x length of seedling.

The data for different characters were compiled and tabulated in proper form and then subjected to statistical analysis following a computer IRRISTAT package programme adjusted the means. The correlation co-efficient were done for different variables wherever needed. 


\section{Results and Discussion}

\section{Moisture percentage}

Observation on moisture percentage in three lentil varieties revealed that varieties differed significantly among themselves in 2004 and non-significant in 2005 (Table 1). The highest moisture percentage $(10.03 \%$ in 2004$)$ was observed in BARI Masur-2, which was statistically different from other two varieties (BARI Masur-3 and BARI Masur-4). The lowest moisture percentage (8.98\% in 2004 and $8.59 \%$ in 2005) was observed in BARI Masur-4. Shahjahan (2003) observed that lentil seeds contained $8.57-11.45 \%$ moisture after nine months of storing in six types of containers. There was non-significant effect of harvesting stage on moisture percentage in both the years (Table 2). Pods collected at the stage of yellow with a few yellow green $\left(\mathrm{H}_{1}\right.$ stage) recorded higher moisture percentage $9.60 \%$ in 2004 and $9.00 \%$ in 2005. The lowest moisture $(9.33 \%$ in 2004 and $8.72 \%$ in 2005) was observed by the seeds that was collected at the stage of light brown with a few yellow green $\left(\mathrm{H}_{2}\right)$. Mehta et al. (1993) reported that seeds harvested at 29 days after anthesis (DAA) showed the highest moisture percentage, while seeds harvested at 45 DAA showed the lowest moisture percentage. Similar results were reported elsewhere (Bharud and Patil, 1990; Kim et al., 1987; Saha, 1987 and Dharmalingam and Basu, 1990). Moisture content was the highest in $\mathrm{H}_{1}$ stage i.e. seeds collected at 30 days after flowering (DAF) and the lowest moisture content in $\mathrm{H}_{3}$ stage i.e. at 40 DAF (Mahesha et al., 2001a). The decrease in seed moisture content (Robertson et al., 1978), increase in test weight (Robertson et al., 1978, Adetunji, 1991) and germination percentage (Shete et al., 1992) were reported with the advancement of harvesting dates. The interaction between varieties and harvesting stages was nonsignificant for moisture percentage (Table 3). Moisture percentage was the highest due to the interaction effect of BARI Masur- $2 \mathrm{x}$ yellow pods with a few yellow green $\left(\mathrm{V}_{3} \times \mathrm{H}_{1}\right)$. The lowest moisture percentage was observed in $\mathrm{V}_{3} \times \mathrm{H}_{2}$ in 2004 and in $\mathrm{V}_{3} \times \mathrm{H}_{1}$ and $\mathrm{V}_{3} \times \mathrm{H}_{3}$ in 2005. In all the varieties, $\mathrm{H}_{1}$ gave the highest moisture percentage and $\mathrm{H}_{2}$ gave the lowest moisture percentage (Mahesha et al., 2001 a).

\section{Germination percentage}

The tested lentil varieties did not differ in germination percentage in both the seasons (Table 1). Among three varieties, germination percentage was higher in BARI Masur-4. Shahjahan (2003) found that lentil seeds recorded 87.8-92.9\% germination after nine months of storing in different containers. Singh (1992) also reported that effect of different varieties on germination were significant. Mean lowest germination was $67 \%$ in Pusa-109 and the highest was $76 \%$ in 
Table 1. Effects of different varieties of lentil on different parameters under laboratory condition.

\begin{tabular}{|c|c|c|c|c|c|c|c|c|}
\hline Variety & $\begin{array}{c}\text { Moisture } \\
\text { (\%) }\end{array}$ & $\begin{array}{c}\text { Germination } \\
(\%)\end{array}$ & $\begin{array}{l}\text { Dry } \\
\text { wt } \\
(g)\end{array}$ & $\begin{array}{c}\text { Root } \\
\text { length } \\
(\mathrm{cm})\end{array}$ & $\begin{array}{l}\text { Shoot } \\
\text { length } \\
(\mathrm{cm})\end{array}$ & $\begin{array}{c}\text { Seedling } \\
\text { length } \\
(\mathrm{cm})\end{array}$ & $\begin{array}{l}\text { Vigour } \\
\text { index-I }\end{array}$ & $\begin{array}{l}\text { Vigour } \\
\text { index-Il }\end{array}$ \\
\hline \multicolumn{9}{|c|}{2004} \\
\hline $\begin{array}{l}\text { BARI } \\
\text { Masur-2 }\end{array}$ & 10.03a & 93.3 & $0.80 \mathrm{~b}$ & $8.17 b$ & $8.27 b$ & $16.46 b$ & $75.0 \mathrm{~b}$ & $1536 b$ \\
\hline $\begin{array}{l}\text { BARI } \\
\text { Masur-3 }\end{array}$ & $9.43 \mathrm{~b}$ & 95.4 & $0.88 \mathrm{~b}$ & $8.53 b$ & 8.44ab & $16.98 \mathrm{~b}$ & $83.8 b$ & $1622 \mathrm{ab}$ \\
\hline $\begin{array}{l}\text { BARI } \\
\text { Masur-4 }\end{array}$ & $8.98 c$ & 96.3 & $0.99 a$ & $9.02 \mathrm{a}$ & $9.06 a$ & 18.08a & $96.2 \mathrm{a}$ & $1744 a$ \\
\hline $\mathrm{SE}( \pm)$ & 0.089 & - & 0.021 & 0.10 & 0.18 & 0.18 & 2.39 & 30.03 \\
\hline Sig. & $* *$ & $\mathrm{~ns}$ & $* *$ & $* *$ & $* *$ & $* *$ & $* *$ & $* *$ \\
\hline \multicolumn{9}{|c|}{2005} \\
\hline $\begin{array}{l}\text { BARI } \\
\text { Masur-2 }\end{array}$ & 9.21 & 93.4 & 0.86 & 9.63 & 8.43 & 18.18 & 80.2 & 1701 \\
\hline $\begin{array}{l}\text { BARI } \\
\text { Masur-3 }\end{array}$ & 8.76 & 95.3 & 0.87 & 9.71 & 8.44 & 18.26 & 82.6 & 1752 \\
\hline $\begin{array}{l}\text { BARI } \\
\text { Masur-4 }\end{array}$ & 8.59 & 96.3 & 0.88 & 10.24 & 8.78 & 19.02 & 85.1 & 1835 \\
\hline $\mathrm{SE}( \pm)$ & - & - & - & - & - & - & - & - \\
\hline Sig. & ns & ns & ns & ns & ns & ns & ns & ns \\
\hline
\end{tabular}

In a column, the figure(s) having same letter are not significantly different.

**significant at $1 \%$ level, NS: Not significant.

variety Pusa-34. The highest germination of $90 \%$ over all the varieties was recorded in seed collected from Nagpur location and the lowest of 62\% at Delhi and Mainpuri. They observed that lentil variety L9-12 gave 93\% germination and HP1-5 gave 85\% germination. Bhingarde and Dumbre (1993) reported that large sized seed gave higher germination percentage (48\%) and smaller size seed gave lower germination percentage (46.0\%). Borate et al. (1993) observed that germination was higher (89.6\%) in large size seeds and lower (85.2\%) in small size seed of groundnut. Mahesha et al. (2001 b) reported that varieties differed significantly on germination percentage. Harvesting stage markedly increased the germination percentage in 2004 (Table 2). Seeds collected in $\mathrm{H}_{2}$ stage gave the highest germination percentage (97.4\% in 2004 and 96.9\% in 2005). The lowest germination percentage was observed in $\mathrm{H}_{1}$ stage. It indicated that germination was markedly less in early harvested seeds compared to seeds harvested at later stages. Lesser germination (\%) in early harvested seeds may due to presence of more number of immature and unfilled seeds. Harvesting the crop earlier resulted 
in poor seed quality owing to immaturity (Jayaraj and Karivaratharaju, 1992). Similar results were reported in sunflower (Mahesha et al., 2001a; Adetunji, 1991; Kandil, 1982). Mehta et al. (1993) reported that seeds harvested at 37 to onwards of DAA recorded higher germination percentage while seeds harvested at 33 DAA showed the lower germination percentage. They also observed that seeds harvested before 33 DAA drastically reduced the germination percentage. Significant differences were also noted in germination due to harvesting. Seed collected 40 days after anthesis registered lowest germination (25.0\%) and it was the highest (91.3\%) on 60th day after anthesis (Jayaraj and Karivaratharaju, 1992). Germination percentage was the highest in $\mathrm{H}_{2}$ stage i.e. seeds collected at 35 days after flowering (DAF) and the lowest in $\mathrm{H}_{1}$ stage i.e. at $30 \mathrm{DAF}$ (Mahesha et al., 2001a, 2001b). The decrease in seed moisture content (Robertson et al., 1978), increase in test weight (Robertson et al., 1978; Adetunji, 1991) and germination percentage (Shete et al., 1992) were reported with the advancement of harvesting dates. The highest germination percentage $(99.3 \%)$ was observed in 2004 by the interaction of BARI Masur- $4 \times \mathrm{H}_{2}$ and $98.7 \%$ in 2005 by the interaction of BARI Masur- $3 \times \mathrm{H}_{3}$ (Table 3). The lowest germination percentage was observed in interaction of BARI Masur- 2 x H1. In all varieties, $\mathrm{H}_{1}$ gave the highest percentage and $\mathrm{H}_{3}$ gave the lowest.

Table 2. Effects of lentil seeds collected from different harvesting stages on different parameters under laboratory condition

\begin{tabular}{|c|c|c|c|c|c|c|c|c|}
\hline $\begin{array}{c}\text { Harvesting } \\
\text { stage }\end{array}$ & $\begin{array}{l}\text { Moisture } \\
(\%)\end{array}$ & $\begin{array}{c}\text { Germination } \\
(\%)\end{array}$ & $\begin{array}{l}\text { Dry wt } \\
\text { (g) }\end{array}$ & $\begin{array}{l}\text { Root } \\
\text { length } \\
(\mathrm{cm})\end{array}$ & $\begin{array}{c}\text { Shoot } \\
\text { length } \\
(\mathrm{cm})\end{array}$ & $\begin{array}{l}\text { Seedling } \\
\text { length } \\
(\mathrm{cm})\end{array}$ & $\begin{array}{l}\text { Vigour } \\
\text { index-I }\end{array}$ & $\begin{array}{l}\text { Vigour } \\
\text { index-Il }\end{array}$ \\
\hline \multicolumn{9}{|c|}{2004} \\
\hline $\mathrm{H}_{1}$ & 9.60 & $92.4 \mathrm{~b}$ & $0.82 b$ & $8.28 b$ & 8.52 & 16.80 & $75.6 \mathrm{~b}$ & $1556 b$ \\
\hline $\mathrm{H}_{2}$ & 9.33 & $97.4 \mathrm{a}$ & $0.93 a$ & 8.79a & 8.66 & 17.47 & $90.7 \mathrm{a}$ & $1704 a$ \\
\hline $\mathrm{H}_{3}$ & 9.51 & $95.2 \mathrm{ab}$ & $0.93 a$ & $8.66 \mathrm{ab}$ & 8.59 & 17.24 & $88.7 \mathrm{a}$ & 1643ab \\
\hline $\mathrm{SE}( \pm)$ & - & 1.27 & 0.021 & 0.10 & - & - & 2.39 & 30.04 \\
\hline Sig. & ns & $*$ & $* *$ & $* *$ & ns & ns & $* *$ & $* *$ \\
\hline \multicolumn{9}{|c|}{2005} \\
\hline $\mathrm{H}_{1}$ & 9.00 & 93.2 & 0.86 & 9.47 & $8.03 \mathrm{~b}$ & $17.50 \mathrm{~b}$ & 80.1 & $1638 b$ \\
\hline $\mathrm{H}_{2}$ & 8.72 & 96.9 & 0.88 & $\begin{array}{l}10.28 \\
J\end{array}$ & $9.30 a$ & 19.69a & 81.9 & $1918 a$ \\
\hline H3 & 8.83 & 94.9 & 0.87 & $9.84 \mathrm{j}$ & $8.32 b$ & 18.28ab & 82.9 & 1732ab \\
\hline $\mathrm{SE}( \pm)$ & - & - & - & - & 0.294 & 0.48 & - & 49.40 \\
\hline Sig. & ns & ns & ns & ns & $*$ & $*$ & ns & $* *$ \\
\hline
\end{tabular}

In a column, the figure(s) having same letter are not significantly different.

*significant at $5 \%$ level, **significant at $1 \%$ level, ns: Not significant.

$\mathrm{H}_{1}$ : When pods were yellow with a few yellow green

$\mathrm{H}_{2}$ : Most pods were light brown with a few yellow green

$\mathrm{H}_{3}$ : All the pods were completely brown and dry 
Table 3. Interaction effects of lentil varieties and seeds collected from different harvesting stages on different parameters under laboratory condition.

\begin{tabular}{|c|c|c|c|c|c|c|c|c|}
\hline Treatment & $\begin{array}{l}\text { Moisture } \\
(\%)\end{array}$ & $\begin{array}{c}\text { Germination } \\
\text { (\%) }\end{array}$ & $\begin{array}{l}\text { Dry wt } \\
\text { (g) }\end{array}$ & \begin{tabular}{|c|} 
Root \\
length \\
$(\mathrm{cm})$
\end{tabular} & $\begin{array}{c}\text { Shoot } \\
\text { length } \\
(\mathrm{cm})\end{array}$ & $\begin{array}{l}\text { Seedling } \\
\text { length } \\
(\mathrm{cm})\end{array}$ & $\begin{array}{l}\text { Vigour } \\
\text { index-I }\end{array}$ & $\begin{array}{l}\text { Vigour } \\
\text { index- } \\
\text { Il }\end{array}$ \\
\hline \multicolumn{9}{|c|}{2004} \\
\hline $\mathrm{V}_{1} \mathrm{H}_{1}$ & 10.29 & 91.0 & $0.77 c$ & $7.97 c$ & 8.13 & 16.10 & $70.3 c$ & 1465 \\
\hline $\mathrm{V}_{1} \mathrm{H}_{2}$ & 9.83 & 95.7 & $0.75 c$ & $8.13 b c$ & 8.27 & 16.47 & $71.5 c$ & 1574 \\
\hline $\mathrm{V}_{1} \mathrm{H}_{3}$ & 9.96 & 93.3 & $0.89 \mathrm{bc}$ & $8.40 b c$ & 8.40 & 16.80 & 83.3bc & 1569 \\
\hline $\mathrm{V}_{2} \mathrm{H}_{1}$ & 9.49 & 92.3 & $0.83 b c$ & $8.40 b c$ & 8.20 & 16.60 & $76.6 \mathrm{bc}$ & 1534 \\
\hline $\mathrm{V}_{2} \mathrm{H}_{2}$ & 9.35 & 97.3 & $0.83 b c$ & $8.47 b c$ & 8.67 & 17.13 & $80.5 b c$ & 1669 \\
\hline $\mathrm{V}_{2} \mathrm{H}_{3}$ & 9.46 & 96.7 & $0.98 \mathrm{~b}$ & $8.73 b c$ & 8.47 & 17.20 & $94.4 \mathrm{~b}$ & 1663 \\
\hline $\mathrm{V}_{3} \mathrm{H}_{1}$ & 9.02 & 94.0 & $0.85 b c$ & $8.47 b c$ & 9.23 & 17.70 & $80.0 \mathrm{bc}$ & 1667 \\
\hline $\mathrm{V}_{3} \mathrm{H}_{2}$ & 8.80 & 99.3 & $1.21 \mathrm{a}$ & $9.77 a$ & 9.03 & 18.80 & $120.2 \mathrm{a}$ & 1868 \\
\hline $\mathrm{V}_{3} \mathrm{H}_{3}$ & 9.11 & 95.7 & $0.92 b c$ & $8.83 \mathrm{~b}$ & 8.90 & 17.73 & $88.4 \mathrm{bc}$ & 1696 \\
\hline $\mathrm{SE}( \pm)$ & - & - & 0.037 & 0.17 & - & - & 4.14 & - \\
\hline Sig. & ns & ns & $* *$ & $* *$ & ns & ns & $* *$ & ns \\
\hline CV (\%) & 2.8 & 4.0 & 7.1 & 3.4 & 5.0 & 3.2 & 8.4 & 5.5 \\
\hline \multicolumn{9}{|c|}{2005} \\
\hline $\mathrm{V}_{1} \mathrm{H}_{1}$ & 9.57 & 90.0d & $0.91 a$ & $7.20 \mathrm{~b}$ & 7.76 & $14.96 b$ & $82.2 a$ & $1343 c$ \\
\hline $\mathrm{V}_{1} \mathrm{H}_{2}$ & 8.90 & 97.4abc & $0.83 b c$ & 11.10a & 9.13 & $20.57 a$ & $80.5 b$ & $2005 a$ \\
\hline $\mathrm{V}_{1} \mathrm{H}_{3}$ & 9.17 & 92.7bcd & $0.84 \mathrm{bc}$ & $10.60 \mathrm{a}$ & 8.40 & $19.00 \mathrm{a}$ & $77.7 \mathrm{~b}$ & 1754ab \\
\hline $\mathrm{V}_{2} \mathrm{H}_{1}$ & 8.90 & $91.7 \mathrm{~cd}$ & 0.88ab & $9.91 \mathrm{a}$ & 7.40 & 17.30ab & $80.6 b$ & $1588 b c$ \\
\hline $\mathrm{V}_{2} \mathrm{H}_{2}$ & 8.57 & 95.7abc & $0.82 b c$ & $9.50 \mathrm{a}$ & 9.45 & $18.95 a$ & $78.5 \mathrm{~b}$ & $1840 \mathrm{ab}$ \\
\hline $\mathrm{V}_{2} \mathrm{H}_{3}$ & 8.80 & $98.7 \mathrm{a}$ & $0.90 \mathrm{ab}$ & $9.72 \mathrm{a}$ & 8.47 & $18.54 a$ & 88.8ab & 1830ab \\
\hline $\mathrm{V}_{3} \mathrm{H}_{1}$ & 8.53 & 98.0ab & $0.79 c$ & $11.30 \mathrm{a}$ & 8.93 & $20.23 a$ & $77.4 \mathrm{~b}$ & 1983a \\
\hline $\mathrm{V}_{3} \mathrm{H}_{2}$ & 8.70 & $97.7 \mathrm{ab}$ & $0.98 a$ & $10.23 a$ & 9.31 & 19.54a & $95.7 \mathrm{a}$ & 1909ab \\
\hline $\mathrm{V}_{3} \mathrm{H}_{3}$ & 8.53 & 93.3abc & 0.88abc & $9.20 \mathrm{ab}$ & 8.09 & 17.29ab & 82.2ab & $1612 b c$ \\
\hline SE ( \pm$)$ & - & 1.74 & 0.024 & 0.545 & - & 0.83 & 3.05 & 85.57 \\
\hline Sig. & ns & $*$ & $* *$ & $* *$ & ns & $* *$ & $* *$ & $* *$ \\
\hline CV (\%) & 7.4 & 3.2 & 4.8 & 9.6 & 10.3 & 7.8 & 6.4 & 8.4 \\
\hline
\end{tabular}

In a column, the figure(s) having same letter are not significantly different.

* Significant at 5\% level, **significant at 1\% level, ns: Not significant.

$\mathrm{V}_{1} \mathrm{H}_{1}$ : BARI Masur- $2 \times$ When pods were yellow with a few yellow green

$\mathrm{V}_{1} \mathrm{H}_{2}$ : BARI Masur- $2 \times$ Most pods were light brown with a few yellow green

$\mathrm{V}_{1} \mathrm{H}_{3}$ : BARI Masur- $2 \times$ All the pods were completely brown and dry

$\mathrm{V}_{2} \mathrm{H}_{1}$ : BARI Masur-3 $\times$ When pods were yellow with a few yellow green

$\mathrm{V}_{2} \mathrm{H}_{2}$ : BARI Masur-3 $\times$ Most pods were light brown with a few yellow green

$\mathrm{V}_{2} \mathrm{H}_{3}$ : BARI Masur-3 $\times$ All the pods were completely brown and dry

$\mathrm{V}_{3} \mathrm{H}_{1}$ : BARI Masur- $4 \times$ When pods were yellow with a few yellow green

$\mathrm{V}_{3} \mathrm{H}_{2}$ : BARI Masur- $4 \times$ Most pods were light brown with a few yellow green

$\mathrm{V}_{3} \mathrm{H}_{3}$ : BARI Masur- $4 \times$ All the pods were completely brown and dry 


\section{Dry weight}

Shoot dry weight of BARI Masur varieties was significant in 2004 but nonsignificant in 2005. BARI Masur-4 recorded the highest shoot dry weight, which was significant over other two varieties in 2004. The lowest dry weight in both the years was observed in BARI Masur-2 (Table 1). Tomar et al. (2000) reported that among four varieties of lentil genotype Pant L 639 recorded significantly higher dry weight. Harvesting stage significantly increased the dry weight of shoot in 2004 (Table 2). The maximum shoot dry weight (0.93 g/plant in 2004) was recorded in the harvesting stage of $\mathrm{H}_{2}$ and $\mathrm{H}_{3}$, which significantly differed from $\mathrm{H}_{1}$. Harvesting stage had no effect on dry weight in 2005, though the maximum shoot weight ( $0.88 \mathrm{~g} /$ plant) was noted in the harvesting stage of $\mathrm{H}_{2}$. Dry weight was the highest in $\mathrm{H}_{2}$ stage i.e. seeds collected at 35 days after flowering (DAF) and the lowest in $\mathrm{H}_{1}$ stage i.e. at $30 \mathrm{DAF}$ (Mahesha et al., 2001b). The effect of variety $\times$ harvesting stage on shoot dry weight was significant (Table 3). The maximum shoot dry weight (1.21 g/plant in 2004 and $0.98 \mathrm{~g}$ /plant in 2005) was recorded by BARI Masur-4 $\times \mathrm{H}_{2}$, which was significantly different from all other treatments in 2004 and identical to $\mathrm{V}_{1} \times \mathrm{H}_{1}$, $\mathrm{V}_{2} \times \mathrm{H}_{1}, \mathrm{~V}_{2} \times \mathrm{H}_{3}$ and $\mathrm{V}_{3} \times \mathrm{H}_{3}$ in 2005. The minimum shoot dry weight was observed in BARI Masur- 2 x $\mathrm{H}_{2}$ in 2004 and in BARI Masur- $4 \times \mathrm{H}_{1}$ in 2005.

\section{Root length}

The maximum root length $(9.02 \mathrm{~cm}$ in 2004) produced by BARI Masur-4 was significantly superior to other two varieties (Table 1). In 2005, root length was also higher in BARI Masur-4 though the length was at par with other two varieties. The lowest root length was recorded by BARI Masur-2. Singh (1992) observed that L 9-12 gave higher root length of $7.2 \mathrm{~cm}$ and HP L-5 gave the lower root length of $6.7 \mathrm{~cm}$. Harvesting stage produced significantly higher root length in 2004 only (Table 2). The highest root length was recorded in the $\mathrm{H}_{2}$ stage, which was similar to $\mathrm{H}_{3}$ The lowest root length was found in $\mathrm{H}_{1}$. The effect of harvesting stage on root length of three lentil varieties revealed that root length was markedly improved by harvesting stages in all the varieties (Table 3 ). In BARI Masur-4, $\mathrm{H}_{2}$ harvesting stage resulted in maximum root length $(9.77 \mathrm{~cm})$ in 2004 and BARI Masur-4 $\mathrm{x} \mathrm{H}_{1}(11.30 \mathrm{~cm})$ in 2005. Interaction effect of BARI Masur- $2 \mathrm{x} \mathrm{H}_{1}$ recorded the lowest root length.

\section{Shoot length}

The maximum shoot length of $9.06 \mathrm{~cm}$ in 2004 and $8.78 \mathrm{~cm}$ in 2005 was produced by BARI Masur-4, which was similar to BARI Masur-3 in 2004 (Table 1). The lowest shoot length was noted in BARI Masur-2. Singh (1992) observed that L 9-12 gave higher shoot length of $9.8 \mathrm{~cm}$ and HP L-5 gave the lower shoot length of $8.6 \mathrm{~cm}$. Harvesting stage of $\mathrm{H}_{2}$ showed significantly 
better shoot length (Table 2). Significantly higher shoot length $(9.30 \mathrm{~cm})$ was produced with $\mathrm{H}_{2}$ in 2005-06. But in 2004-05, shoot length was also higher with $\mathrm{H}_{2}$ though the value was non-significant. Interaction of variety $\times$ harvesting stage did not differ significantly in respect of shoot length (Table 3). The highest shoot length of $9.23 \mathrm{~cm}$ was recorded by the interaction of $\mathrm{V}_{3} \times \mathrm{H}_{1}$ in 2004 and $9.45 \mathrm{~cm}$ by the interaction of $\mathrm{V}_{2} \times \mathrm{H}_{2}$ in 2005. The lowest shoot length was observed in $\mathrm{V}_{1} \times \mathrm{H}_{1}$.

\section{Seedling length}

The maximum seedling length $(18.08 \mathrm{~cm})$ was noted by BARI Masur-4, which was significantly superior to other two varieties in 2004 (Table 1). The same variety recorded maximum shoot length in 2005, which was statistically identical to other two varieties. Mahesha et al. (2001b) reported that varieties differed significantly on seedling length. Harvesting stage produced significantly higher seedling length only in 2005 (Table 2). The highest seedling length was recorded in $\mathrm{H}_{2}$ stage, which might have been resulted from higher germination percentage and vigorous growth. Seedling length was the highest in $\mathrm{H}_{2}$ stage i.e. seeds collected at 35 days after flowering (DAF) and the lowest in $\mathrm{H}_{1}$ stage i.e. at 30 DAF (Mahesha et al., 2001b). The effect of harvesting stage on root plus shoot length of three lentil varieties revealed that seedling length was markedly improved by harvesting stages in all the varieties in 2005 (Table 3). The maximum seedling length was observed by the interaction of $\mathrm{V}_{3} \times \mathrm{H}_{2}$ in 2004 and by $\mathrm{V}_{1} \times \mathrm{H}_{2}$ in 2005. The minimum root plus shoot length was noted in $\mathrm{V}_{1} \times \mathrm{H}_{1}$.

\section{Vigour index}

The maximum vigour index-I (96.2 in 2004) was produced by BARI Masur-4, which was statistically different from other two varieties (Table 1). This might be due to higher germination percentage and dry weight. Similarly, the highest vigour index-I (85.1) was observed in 2005, which was similar to other two varieties in 2005. The lowest vigour index-I (75.0 in 2004 and 80.2 in 2005) was noted in BARI Masur-2. BARI Masur-4 gave significantly higher vigour index$\mathrm{T}_{1}$ over BARI Masur-2, but identical to BARI Masur-3 in 2004 (Table 1). Lower vigour index- $\mathrm{T}_{1}$ was noted in BARI Masur-2. Decrease of the vigour index-Il in BARI Masur-2 might be due to lower germination percentage and seedling length (Khare and Satpute, 1999). Similar varietal difference was reported by Matthews (1973) in peas. Borate et al. (1993) observed that vigour index- $T_{1}$ was higher (2568) in large size seeds and lower (2111) in small size seeds of groundnut. Harvesting stage showed significantly better vigour index-I in 2004 only (Table 2). Higher vigour index-I was produced with $\mathrm{H}_{2}$ harvesting stage, which was similar to $\mathrm{H}_{3}$. The lowest vigour index-I was observed by $\mathrm{H}_{1}$. 
Harvesting the seed before the attainment of physiological maturity recorded lesser viability and vigour potentials due to more number of immature seeds with relatively low degree of embryo development and high moisture content as reported in pea by Matthews (1973). Harvesting stage of $\mathrm{H}_{2}$ markedly increased vigour index-II (Table 2). Seeds harvested at the stage of light brown with a few yellow green of pods $\left(\mathrm{H}_{2}\right)$ showed appreciably higher seed vigour index-Il probably due to associative effect of germination percentage and seedling length. Increased seed vigour index-II might be due to maturation of seeds in $\mathrm{H}_{2}$ stage resulting in improvement of germination percentage and seedling length (Gore et al., 1997). Khare and Satpute (1999) reported similar results. The vigour index showed a steady increase from 1592 to 26454 with the advancement of days after anthesis from 40 to 60 . Interaction of variety $\mathrm{x}$ harvesting stage differed significantly in respect of vigour index-I (Table 3). In BARI Masur-4, harvesting stage of $\mathrm{H}_{2}$ resulted the maximum vigour index-I. The highest seed vigour indexI (120.2 in 2004 and 95.7 in 2005) was observed by the interaction of BARI Masur- $4 \times \mathrm{H}_{2}$. The vigour index-I recorded by $\mathrm{V}_{3} \times \mathrm{H}_{2}$ was statistically different from all other treatment combinations in 2004 and similar to $\mathrm{V}_{1} \times \mathrm{H}_{1}, \mathrm{~V}_{2} \times \mathrm{H}_{3}$ and $\mathrm{V}_{3} \times \mathrm{H}_{3}$ The lowest vigour index-I was noted by the interaction of BARI Masur-2 $\mathrm{x} \mathrm{H}_{1}$ in 2004 and by BARI Masur- $2 \mathrm{x} \mathrm{H}_{3}$ in 2005. All the varieties of BARI Masur responded significantly to harvesting stage, producing higher seed vigour index-II in 2005 (Table 3). The highest seed vigour index-II was recorded by interaction of $\mathrm{V}_{3} \times \mathrm{H}_{2}$ in 2004 and by $\mathrm{V}_{1} \times \mathrm{H}_{2}$ in 2005. The lowest seed vigour index-II was noted by $\mathrm{V}_{1} \times \mathrm{H}_{1}$ in both the years.

\section{Correlation}

Correlation matrix among the plant characters of lentil has been shown in Table 4. A positive and significant correlation was observed between germination percentage and seedling length (2004), vigour index-I (2004 and 2005), vigour index-II (2004 and 2005); dry weight and seedling length (2004), vigour index-I (2004 and 2005), vigour index-II (2004); seedling length and vigour index-I (2004), vigour index-II (2004 and 2005); vigour index-I and vigour index-II (2004). A negative correlation was found between moisture percentage and germination percentage, dry weight (2005), seedling length, vigour index-I and vigour index-II in both the years. A positive correlation $(\mathrm{r}=0.596)$ between germination and dry matter was shown (Mehta et al., 1993). They also observed that germination showed negative correlations $(\mathrm{r}=0.856)$ with moisture content of seed and ( $\mathrm{r}=0.573$ ) with fresh weight of pod wall. Reddy and Khan (2001) found a positive and significant correlation between germination and seedling dry weight $\left(0.68^{* *}\right)$, vigour index-I $\left(0.91^{* *}\right)$ and vigour index-II $\left(0.97^{* *}\right)$. Similar results were reported by Baburatan et al. (1993) and Ponnuswamy et al. (1991). 
Table 4. Correlation matrix among different parameters of lentil.

\begin{tabular}{l|l|l|c|c|c|c}
\hline \multirow{2}{*}{ Characters } & \multirow{2}{*}{ Year } & \multicolumn{5}{c}{ Correlation coefficient (r value) } \\
\cline { 3 - 7 } & & Germination & $\begin{array}{c}\text { Dry } \\
\text { weight }\end{array}$ & $\begin{array}{c}\text { Seedling } \\
\text { length }\end{array}$ & $\begin{array}{c}\text { Vigour } \\
\text { index-I }\end{array}$ & $\begin{array}{c}\text { Vigour } \\
\text { index-Il }\end{array}$ \\
\hline Moisture & 2004 & $-0.337 \mathrm{~ns}$ & $0.504^{* *}$ & $0.686^{* *}$ & $0.524^{* *}$ & $0.602^{* *}$ \\
& 2005 & $0.496^{* *}$ & $0.077 \mathrm{~ns}$ & $-0.194 \mathrm{~ns}$ & $-0.185 \mathrm{~ns}$ & $-0.319 \mathrm{~ns}$ \\
\hline Germination & 2004 & & $0.368 \mathrm{~ns}$ & $0.548^{* *}$ & $0.560^{* *}$ & $0.844^{* *}$ \\
& 2005 & & -0.01 ins & $0.350 \mathrm{~ns}$ & $0.497^{* *}$ & $0.594^{* *}$ \\
\hline Dry weight & 2004 & & $0.614^{* *}$ & $0.976^{* *}$ & $0.582^{* *}$ \\
& 2005 & & $-0.277 \mathrm{~ns}$ & $0.862^{* *}$ & $-0.240 \mathrm{~ns}$ \\
\hline Seedling & 2004 & & & $0.677^{* *}$ & $0.911^{* *}$ \\
length & 2005 & & & & $-0.064 \mathrm{~ns}$ & $0.959^{* *}$ \\
\hline Vigour-I & 2004 & & & & $0.716^{* *}$ \\
& 2005 & & & & $0.092 \mathrm{~ns}$ \\
\hline
\end{tabular}

* Significant at 5\% level, ** Significant at 1\% level, ns: Not significant.

\section{References}

Adetunji, I. A. 1991. Effect of harvest date on seed quality and viability of sunflower in semiarid tropics. Seed Sci. \& Tech. 19: 57 1-580.

Baburatan, P., S. Eswarareddy and Y. Narayanareddy. 1993. Influence of water soaking of Annona (Annona squamosa L.) seed on germination and subsequent seedling growth. South Indian Hort. 41: 171-173.

Bharud, R. W. and R. B. Patil. 1990. Studies on physiological maturity of gram (Cicer arietnum L.) seeds. Seed Res. 18: 160-162.

Bhingarde, M. T. and A. D. Dumbre. 1993. Effect of seed size on growth and yield components in greengram (Vigna radiata L. Wilezek) under summer conditions. Seed Res. 21(2): 104-106.

Borate, D. N., A. D. Dumbre and M. T. Bhingarde. 1993. Effect of seed size on growth, yield and seed quality of groundnut (Arachis hypogaea L.) under summer conditions. Seed Res. 21(2): 107-109.

Deshpande, V. K., G. N. Kulkarni and M. B. Kurdikeri. 1991. Storability of maize as influenced by time of harvesting. Curr. Res. 20: 205-207.

Dharmalingam, C. and R. N. Basu. 1990. Seed development and maturation studies in mungbean. Seed Res. 18: 1-16.

Gore, S. V., R. B. Patil and G. R. Wankhade. 1997. Effect of maturity period and harvesting time on seed quality in soybean (Glycine max. [L.] Merill) cultivars. Seed Res. 25(1): 45-49.

ISTA (International Seed Testing Association). 1976. International Rules for Seed Testing. Seed Sci. and Tech. 4: 3-49.

Jayaraj, T. and T. V. Karivaratharaju. 1992. Influnce of harvesting stage on seed vigour in groundnut cultivar. Seed Res. 20(1): 41-43. 
Kandil, A. E. A. 1982. Effect of harvesting date on oil yield and its components on sunflower. Ann. Agric. Sci. 17: 23-25.

Khare, D. and R. G. Satpute. 1999. Influence of days to maturity and seed size on germination and seedling vigour in pigeonpea. Seed Res. 27(2): 170-173.

Kim, S. D., Y. H., Cha, J. T. Cho, K. C. Kwon, S. G. Son and S. I. Park. 1987. Changes in development and nutrient composition of pod after flowering in cowpea (Vigna unguiculata L.). Korean J. Crop. Sci. 31: 68-73.

Kole, S. and K. Gupta. 1982. The timing of physiological maturity of seeds of sunflower: evaluation through multiple tests. Seed Sci. \& Tech. 10: 457-467.

Mahesha, C. R., A. S. Channaveeraswami, M. B. Kurdikeri, M. Shekhargouda and M. N. Merwade. 2001a. Seed maturation studies in sunflower genotypes. Seed Res. 29(1): 95-97.

Mahesha, C. R., A. S. Channaveeraswami, M. B. Kurdikeri, M. Shekhargouda and M. N. Merwade. 200lb. Storability of sunflower seeds harvested at different maturity dates. Seed Res. 29(1): 98-102.

Matthews. S. 1973. The effect of time of harvest on the viability and pre-emergence mortality in soil of pea (Pisum sativum L.) seeds. Ann. Appi. Biol. 73(2): 211-219.

Mehta, C. J., M. S. Kuhad, I. S. Sheoran and A. S. Nandwal. 1993. Studies on seed development and germination in chickpea cultivars. Seed Res. 21(2): 89-91.

Morshed, M. S., M. Begum, M. A. Bashar and W. Sultana. 2003. Effect of storage containers on seed quality of three pulses. Bangladesh J. Life Sci. 15(1): 107-112.

Ponnuswamy, R. L., R. H. Miller and W. H. Luckmann. 1991. Introduction to Insect Pest Management. John Wiley and Sons. New York. 235-273 pp.

Reddy, Y. T. N. and M. M. Khan. 2001. Effect of osmopriming on germination, seedling growth and vigour of khirni (Mimusops hexandra) seeds. Seed Res. 29(1): 24-27.

Robertson, J. A., J. V. G. R. Chapman and J. R. R. L. Nwilson. 1978. Relation of days after flowering to chemical composition and physiological maturity of sunflower seed. Amer. Oil Chemist Soc. J. 35: 266-269.

Saha, A. 1987. Physiology of seed development in urdbean. Indian J. Plant Physiol. 30: 199- 201.

Shahjahan, M. 2003. Storage effect on the nutritional quality of three major pulses. Ph. D. Thesis, Department of Biochemistry and Molecular Biology, University of Dhaka.

Shete, D. M., A. R. Singh, A. P. Suryawanshi and V. S. Hudge. 1992. Seed germination and vigour as influenced by seed position and stage of harvest in sunflower. Ann. Plant Physiol. 6: 125-132.

Singh, N. 1992. Genotype x environment interaction for seed germination and seeding vigour in upland cotton. Seed Res. 20(1): 7-9.

Singh, A. R. and A. Lachanna. 1995. Effect of dates of harvesting, drying and storage on seed quality of sorghum parental lines. Seed Res. 13: 180-185.

Tomar, S. K., P. Tripathi and A. L. Rajput. 2000. Effect of genotype, seeding method and diammonium phosphate on yield and protein and nutrient uptake by lentil (Lens culinaris). Indian J. Agron. 45(1): 148-152. 